Copyright (C) 2021 by Cherkas Global University

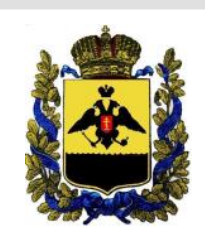

Published in the USA

Bylye Gody

Has been issued since 2006.

E-ISSN: 2310-0028

2021. 16(4): 1886-1897

DOI: $10.13187 /$ bg.2021.4.1886

Journal homepage:

https://bg.cherkasgu.press

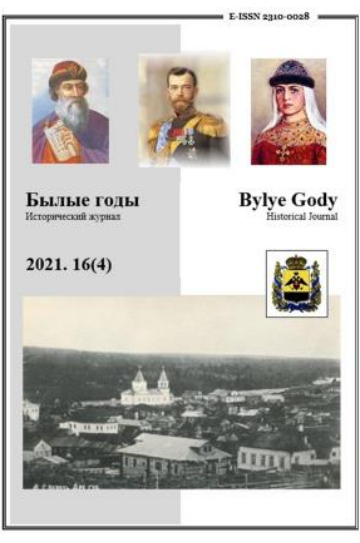

\title{
Sport Societies and Leisure Time in Rostov-on-Don at the turn of the $19^{\text {th }}-\mathbf{2 0}^{\text {th }}$ centuries
}

\author{
Maria V. Bratolyubova a , * \\ ${ }^{a}$ Southern Federal University, Russian Federation
}

\begin{abstract}
The article is devoted to an important component of Rostov-on-Don city life - leisure time at the end of XIX - beginning of XX century. Within the framework of the article the sports aspect of the history of leisure in Rostov-on-Don is considered. It shows how at the end of the 19th century the middle-class citizens were inclined to spend their free time together and to choose reasonable and developing forms of leisure activities. In Rostov-on-Don, the development of forms of leisure associated with participation in physical education and sport was rapid. Physical training and sports were becoming popular, taking public forms: societies of skaters and cross-country skiers, cyclists and football players.

The author concludes that since the last quarter of the $19^{\text {th }}$ century sports in Rostov-on-Don became a fashionable and universal hobby, the first sports clubs were formed and the first competitions were organized. Some types of sport evolved into professional sports and by the turn of the $19^{\text {th }}-20^{\text {th }}$ centuries they turned into mass spectacles generating excitement among fans (running and horse-racing, wrestling). The article shows how sporting activities were also an opportunity for like-minded people to socialise. Leisure activities created opportunities for self-realisation of citizens and contributed to the development of civil society institutions.

On the eve of the First World War, the fashionable sporting pastime of the townspeople began to take on the features of a sporting competition. However, this trend was interrupted by World War I and the revolutionary upheaval in Russia at the beginning of the $20^{\text {th }}$ century. clubs.

Keywords: Rostov-on-Don, provincial town, sports leisure activities, sports public organizations and

\section{1. Введение}

Крупные города в пореформенной России были не только центрами оживленной торговопромышленной деятельности, но и местом формирования образа жизни, принципиального отличавшегося от жизни сельского обывателя. Этому способствовали и более отчетливое разделение ежедневного времени горожанина на рабочее и досуговое, и возможности организации этого досуга, которые предоставлялись городскими культурно-досуговыми учреждениями. Структура последних включала в себя как развлекательные заведения, так и учреждения, способствующие личностному росту и развитию. Чем крупнее и населеннее был город, тем более широким спектром досуговых организаций он обладал.

При этом следует заметить, что достаточное время для отдыха имели прежде всего те горожане, которых можно отнести к средним слоям населения: предприниматели, высокооплачиваемые служащие в административных учреждениях и в частном бизнесе, инженерно-техническая интеллигенция и лица свободных профессией. Именно в этой среде горожан к концу XIX в. отчетливо обозначились как тенденции к объединению для совместного проведения свободного времени, так и к разумным (развивающим) формам досуговых занятий, к которым можно отнести и организации
\end{abstract}

\footnotetext{
${ }^{*}$ Corresponding author

E-mail addresses: mvbratolyubova@sfedu.ru (M.V. Bratolyubova)
} 
для совместных занятий спортом - спортивные клубы и общества спортсменов-любителей. Спорт как активная форма проведения свободного времени удовлетворяет те потребности человека, которые не удовлетворяются иными формами досуга, обеспечивая отдых и восстановление организма, развитие физических возможностей человека. Спортивные занятия - это прекрасная возможность для общения единомышленников. А некоторые виды спортивных занятий, эволюционируя в профессиональный спорт, уже на рубеже XIX-XX вв. превращались в массовые зрелища, генерировавшие азарт болельщиков (бега и скачки, борьба).

На рубеже XIX-XX вв. Ростов-на-Дону, крупный торговый центр на юге России, обладал всеми необходимыми предпосылками для возникновения здесь спортивных любительских клубов и обществ. К концу XIX в. среди жителей города средние слои составляли, по оценочным подсчетам, 27-30 \%. (Самарина, 2019: 112) Преобладающую часть их составляли предприниматели и собственники городских доходных домов. Среди организаторов первых спортивных обществ и клубов именно они и обнаруживаются в первую очередь. Показательно и то, что спортивные увлечения этих слоев горожан были весьма дорогостоящи и требовали немалых затрат на оборудование и аксессуары.

\section{2. Материалы и методы}

Источники для изучения сюжета немногочисленны и имеют спорадический характер; их сбор и систематизация - весьма трудоемкое занятие. Об одних спортивных организациях можно узнать лишь по сохранившимся уставам, о других - по единичным отчетам или памяткам для членов общества. Очевидно, что большая часть таких документов просто утрачена. Определить перечень спортивных организаций Ростова помогают городские справочные издания «Весь Ростов-на-Дону» и «Весь Ростов и Нахичеван-на-Дону». С конца XIX в. они публиковались ежегодно, но издатели были разные, как и массив и качество представленных в указателях сведений. К сожалению, не все эти ежегодные издания сохранились.

Интересную информацию о городских спортсменах и их достижениях содержат газетные публикации, но они носят случайный характер. Значительная часть упоминаний о деятельности ростовских спортивных организаций - это объявления о проводимых соревнованиях, которые публиковали их устроители. Внимание газетных хроникеров и фельетонистов обычно привлекали либо спортивные рекорды ростовцев, либо забавные казусы, связанные с действиями их обществ. Очень часто фотографии в газетах, сопровожденные лаконичными подписями, являются единственной информацией о прошедших соревнованиях или интересных достижениях городских любителей спорта. В иллюстрированном издании, посвященном 260-летию города, относительно компактно опубликованы любительские фото 3. Рыгельского, участника по крайней мере двух ростовских спортивных обществ начала XX в. - Азовско-Донского яхт-клуба и кружка любителей спорта. Ранее эти визуальные источники, характеризующие занятия ростовцев спортом, не публиковались (Ростов-на-Дону, 2009).

Обширную группу источников представляет опубликованная официальная документация местных спортивных организаций. Спортивные клубы публиковали свои уставы и издавали отчеты о деятельности. Особо следует отметить личный фонд Михаила Борисовича Краснянского (ф. Р-2613), историка и краеведа, основателя ростовского краеведческого музея. Фонд хранится в Государственном архиве Ростовской области, содержит личные записки и комментарии М.Б. Краснянского о досуговой жизни, культурных мероприятиях Ростова-на-Дону в начале XX века, список действующих в городе обществ, клубов, музеев, парков и коллекцию уставов общественных объединений донских городов.

При разработке темы применялись социокультурный, историко-сравнительный и историкотипологический методы. Социокультурный подход позволил изучить спортивный досуг как часть городской культуры и повседневной жизни Ростова-на-Дону в конце XIX - начале XX вв. Социокультурный метод помог определить, как в спортивных общественных организациях интегрировались представители разных социальных слоев Ростова-на-Дону, как выстраивалась коммуникация, а также проследить влияние модернизационных процессов начала XX века сквозь призму спортивных увлечений горожан. Историко-сравнительный метод используется для сравнения досуговых организаций в столичных городах и провинции. Также этот метод позволяет соотнести спортивные развлечения с другими досуговыми практиками в городском пространстве Ростова-наДону. Историко-типологический метод позволил выявить содержание изучаемых объектов по совокупности признаков.

\section{3. Обсуждение}

Работы, посвященные изучению культуры повседневности (Литягина, 2007; Ловелл, 2005; Малышева, 2011; Ульянова, 2011) затрагивают вопросы досуга, в том числе и спортивных развлечений. Авторы показывают, как горожане проводили свое свободное время и какое место занимал спорт в их жизни (Войтик, 2013; Гончарова, 2007; Некрылова, 2004; Позняк, 2015; Хмельницкая, 2011; Яхно, 2019). 
Специальных историко-краеведческих исследований по данной теме не проводилось. Вопросы, связанные с развлекательной, праздничной культурой Ростова-на-Дону, затрагивались в ряде работ донских исследователей: Волошиновой, Самариной и др. (Волошинова, 2013; Греков, 1912; Краснянский, 1912; Сидоров, 1996; Чалхушьян, 2002; Чеботарев, 1912; Самарина, 2019).

Ростово-нахичеванское общество поощрения рысистого коннозаводства - единственная организация, удостоившаяся в начале XX в. краткого исторического очерка, явно заказанного его руководством и опубликованного, начиная с первого номера газеты этого общества «Ростовские-наДону бега и скачки». В нем кратко изложены основные вехи развития организации, а описанные факты ценны своей репрезентативностью. (Исторический очерк, 1910). Затем более полувека сюжет не привлекал внимания краеведов. В книге «Спорт на Дону», опубликованной в 1977 г., помещен и краткий очерк о спортивных организациях и спортсменах дореволюционного Ростова. К сожалению, он содержит много фактических неточностей и ошибок, которые выявляются при сопоставлении с доступными репрезентативными источниками, что заставляет настороженно относиться к тем фактам, которые проверить невозможно. Ссылок на источники не приводится, да это и не требуется от популярного издания. В итоге наиболее репрезентативно выглядят несколько опубликованных фото спортсменов-ростовцев. Они сделаны в начале XX в. и подписаны (Кулжинский, Красиловец, 1977: 5-6).

\section{4. Результаты}

Первыми тягу к объединению обнаружили местные любители конских бегов. В исторической справке о деятельности общества отмечено, что идея объединения для устройства ипподрома и организации регулярных бегов и скачек вызывалась потребностями совершенствования селекционной работы и улучшения породы рысистых лошадей. «Мысль об устройстве таких испытаний в Ростове принадлежит трем лицам: И.М. Шапошникову, Н.И. Шпехту и А.Е. Корнелио, которые, интересуясь рысистым спортом, образовали в 1878 году из своей среды кружок любителей конского бега, вошедший в тот же год с ходатайством в городское управление об отводе участка земли под ипподром. Городская дума удовлетворила это ходатайство, и с этого времени кружок под наименованием «Любительского кружка Ростово-Нахичеванского на Дону общества конского бега» начал функционировать, причем деятельность его выразилась в устройстве ежегодных беговых испытаний» (Исторический очерк, 1910).

Таким образом, любители конского бега были крупными предпринимателями Ростова и Нахичевани, связанными, помимо прочих областей бизнеса, и с коннозаводским делом. И.М. Шапошников, один из инициаторов и лидеров кружка, в 1910-х годах содержал призовые конюшни. Его лошади регулярно участвовали как в беговых состязаниях, так и в скачках (Состав призовых, 1911). Кружок как форма объединения любителей рысистого коневодства просуществовал в течение 12 лет, организуя ежегодные состязания на обустроенном в городе ипподроме. В 1890 году он был переименован в «Ростово-Нахичеванское общество охотников конского бега». Общество действовало на основе так называемого «нормального» устава, выработанного Главным управлением государственного коннозаводства. С 1903 года, получив новый типовой устав, оно называлось «Ростово-Нахичеванским обществом поощрения рысистого коннозаводства» (Исторический очерк, 1910).

К концу XIX в. общество включало в себя два отдела - беговой и скаковой. В газетных объявлениях о состязаниях и на афишах каждый из отделов назывался проще и короче: поощрительное беговое общество и поощрительное скаковое общество (Объявление о скачках, 1907). Каждый отдел отвечал за организацию и проведение на ипподроме своей части сезона. Решение всех принципиальных вопросов развития относилось к компетенции общего собрания Общества поощрения рысистого коннозаводства. С 1907 г. его президентом был ростовский градоначальник И.Н. Зворыкин, а вице-президентом - Е.Г. Кундури, наследник знаменитого ростовского табачного фабриканта Я.С. Кушнарева (Исторический очерк, 1910).

Весьма быстро ипподромные соревнования приобрели атрибуты профессионального спорта: с лошадьми работали специально подготовленные тренеры и жокеи, с которыми заключались контракты; призовые суммы владельцам лошадей-победителей генерировали азарт хозяев конюшен, а тотализатор - азарт зрителей. В работе тотализатора общество, неизменно именовавшее себя спортивным, было очень заинтересовано. Оно получало процентные отчисления от сумм, обращавшихся на тотализаторе в тот или иной день состязаний и чаще всего превышавших призовой фонд дня. Газета «Бега и скачки» скрупулезно отчитывалась о суммах, поступивших обществу в виде процентов, и о разыгранных призовых. Даже выборочный и беглый просмотр этой хроники объясняет и прибыльные сезонные балансы общества, и быстрый рост призовых сумм на соревнованиях. Например, 3 ноября 1911 года призов на скачках было разыграно на сумму 3100 рублей, а отчисления обществу от тотализатора составили 4 ооо рублей (Хроника, 1911). Сезонная призовая сумма в начале работы ростовского ипподрома составляла всего 3 тыс. рублей, а в 1912 году достигла уже 6о тысяч (Хроника, 1912).

С убытками общество завершило лишь сезоны 1905-1906 гг. (Исторический очерк, 1910). С одной стороны, повлияли события Первой российской революции. Революции неизменно несут 
бизнесу убытки, даже бизнесу азартных развлечений. С другой - в 1905-1906 гг. в Ростове появились и успешно действовали конкуренты ипподромного тотализатора - борцовские турниры с объявленными премиями для победителей. Устраивались они содержателями гастролировавших в городе цирков, и шапито на углу Малой Садовой и Ткачевского переулка стало центром притяжения азартных завсегдатаев городского ипподрома, «тотошников», как их называли фельетонисты ростовских газет. Свой азарт эти люди поддерживали стихийно сложившейся системой ставок на исход того или поединка борцов. Впрочем, популярность поединков оказалась недолговечной, в отличие от ипподромных соревнований. Уже к 1907 году «тотошники» вернулись в привычный мир бегов и скачек, обеспечивая поощрительному обществу рысистого коннозаводства экономическое процветание. Положение его было настолько прочным, что, продлив в 1913 г. договор на аренду у города земли, общество подвело к территории ипподрома водопровод и обновило постройки.

Еще один вид спортивных увлечений состоятельных горожан - содержание яхт и гонки на них. Азовско-Донской яхт-клуб объединил ростовских представителей этого спорта для богатых в 1903 г., когда яхтсменам удалось арендовать гавань для содержания судов в станице Гниловской. Единственный сохранившийся текст устава клуба датирован 1912 г., что не исключает, конечно, и существования его более ранних вариантов. В 1913 г. «Приазовский край» опубликовал краткое описание празднования 10-летнего юбилея яхт-клуба. Программа торжеств, подготовленных яхтсменами, включала молебен и юбилейный обед 26 мая в летнем помещении клуба в станице Гниловской, а также вечернюю прогулку членов клуба и их гостей на пароходе. Юбилейные гонки для парусников всех классов были 2 июня, для моторных судов - 3 июня, за которыми следовал вечерний банкет (В Яхт-клубе, 1913).

Уставные цели общества заключались в популяризации плавания на парусных, гребных и паровых судах, а также улучшении их постройки: «выработка наилучшего типа судов, плавающих по Дону и Азовскому морю и занимающихся рыболовством, а также практическое подготовление опытных шкиперов и матросов» (Азово-Донской, 1912: 3-4). Наряду с целями практическими, полезными для бизнеса, которых не могли не поставить перед собой ростовские судовладельцы, судостроители, экспортеры хлеба, были цели физического совершенствования: «изучение всякого рода гимнастических упражнений и между прочим плавания, катания на коньках, стрельбы в цель, фехтования и т.п.» (Азово-Донской, 1912: 3-4).

Членство в яхт-клубе могло быть почетным и действительным и, в сравнении с другими клубами, относительно дорогим. Почетные члены освобождались от уплаты вступительных и годичных взносов; а действительные платили вступительный взнос 100 руб. и ежегодные в размере 50. Общее собрание имело право изменять размер единовременного взноса от 50 до 200 руб. Членысотрудники клуба из числа специалистов, необходимых для решения технических и иных профессиональных задач, избирались на два года и могли бесплатно посещать клуб. В АзовскоДонской яхт-клуб принимались только лица мужского пола всех сословий. Не допускались низшие воинские чины, несовершеннолетние, исключенные из Азовско-Донского и иных яхт-клубов, лица «опороченные по суду», воспитанники учебных заведений (Азово-Донской, 1912: 5-6).

В первый год навигации у клубной пристани стояли только две яхты. Однако уже в 1906 году яхт-клуб располагал девятнадцатью суднами, среди которых 10 гребных, 4 моторных и 5 парусных (Отчет Азовско-Донского, б.г.: 3). Благодаря постройке моторного катера с бензиновым мотором, стали возможны ежедневные рейсы от города до клубной пристани и обратно для перевозки членов яхт-клуба и их гостей.

Клуб регулярно проводил соревнования по парусному спорту и гребле, известные за пределами Ростова и привлекавшие иногородних участников. В октябре 1905 г. «Приазовский край» сообщил о начале работы атлетической секции яхт-клуба в летнем помещении Коммерческого клуба, так как клубным помещением в Ростове яхтсмены не сумели обзавестись. «Гимнастические упражнения будут проходить четыре раза в неделю - по понедельникам, вторникам, четвергам и пятницам, врачебная гимнастика для дам - по средам и субботам. Число членов секции все растет. Особенно много их дают кредитные учреждения и крупные конторы, где много служащих иностранцев» (Хроника, 1905). Вполне возможно, что работать в полном объеме именно осенью-зимой 1905 года атлетической секции клуба не удалось из-за революционных событий в Ростове, но характер занятий и контингент лиц, ими заинтересованных, уже вполне определился на все последующее время.

Очевидно, участники атлетической секции яхт-клуба были активными посетителями катков, которые функционировали зимой на открытом воздухе, несмотря на все капризы ростовской погоды. Яхт-клуб заливал свой каток на арендуемой в городском саду площадке. В 1913 г. 3. Рыгельский, геодезист и фотограф, представлял Азовско-Донской яхт-клуб на Первой российской олимпиаде в Киеве. В соревновании по академической гребле он занял третье место (Ростов-на-Дону, 2009: 276).

На посту командора клуба представители крупного бизнеса чередовались с начальниками ростовского порта. Первым командором был управляющий концессионными предприятиями в Ростове Р. Раевский, способствовавший становлению клубных спортивных соревнований. Его сменил В.И. Асмолов, крупный табачный фабрикант и известный в городе меценат, один из учредителей яхтклуба (Отчет Азовско-Донского, б.г.:4-5). 
В последнем десятилетии XIX в. распространенным увлечением жителей Ростова и Нахичевани стала езда на велосипеде. Время объединения любителей велосипедной езды и велотуризма выяснить пока не удалось, но в справочнике «Весь Ростов на 1896 год» указаны Ростово-Нахичеванское общество велосипедистов-любителей и Общество велосипедистов-туристов. Последнее позиционировало себя как отделение Российского общества туристов в Донской области (ГАРО. Ф. 2613. Оп. 1. Д. 71. Л. 35).

Уставные документы обществ не сохранились. В цитируемом справочном издании кратко указаны цели обоих обществ и способы их достижения. Цели велосипедистов-любителей заключались в сближении любителей езды на велосипеде и усовершенствовании в ней, а также в распространении велосипеда «как здорового, удобного, практичного и приятного способа передвижения». Для реализации их предполагалось устройство экскурсий, состязаний, «бега на призы» и проч. Отделение Российского туринг-клуба в качестве цели заявляло «распространение употребления велосипеда для дальних поездок и облегчение их устройства» и предполагало организацию не только экскурсий на велосипедах, но и дорожных гонок (Весь Ростов н/Д, 1896: 194-195).

Таким образом, направления действия обеих организаций в ряде аспектов совпадали, в связи с чем любители велосипедной езды могли участвовать в поездках, организуемых туристами, а последние - принимать участие в гонках на велосипедах, которые устраивали любители велосипедной езды. Способствовала этому и жесткая регламентация передвижения на велосипедах по улицам города, которую установила ростовская городская дума в середине 1890-х. Владельцы велосипедов должны были получать в городской управе именное разрешение и номерной знак на велосипед. Правилами запрещалась быстрая езда по улицам и езда вперегонки; при обгоне экипаже или пешехода должен был даваться звонок, а сам обгон производиться только с левой стороны и «умеренным ходом»; передвижение велосипедистов, даже в спешенном виде, по тротуарам, пешеходным дорожкам, бульварам, скверам и садам запрещалось (Весь Ростов н/Д, 1896: 74).

Неудивительно, что при столь жестких ограничениях ростовские и нахичеванские велосипедисты предпочитали дальние экскурсионные поездки и организацию гонок в специально обустроенных для занятий спортом местах. Первоначально любители соревновались в велогонках на ипподроме Ростово-Нахичеванского общества поощрения рысистого коннозаводства, используя то обстоятельство, что скачки и бега проводились лишь два дня в неделю, а между сезонами бегов и скачек существовал интервал чуть более месяца. Разумеется, беговые дорожки ипподрома не вполне подходили для велосипедных гонок. Летом 1895 г. ростовский купец В.И. Асмолов на принадлежавшем ему незастроенном месте - на восточной окраине города, однако на главной улице Ростова - устроил циклодром специально для велосипедных гонок. Это обстоятельство стимулировало городских велосипедистов-любителей. «Предстоящий велосипедный сезон в Ростове обещает быть очень оживленным, причем на одном из треков предполагается устроить состязание двух бензиномоторов и затем гонки с довольно крупными призами, с участием известных иногородних спортсменов», - сообщал «Приазовский край» в 1897 г. (Хроника, 1897).

Велосипедные гонки и состязания на прообразах мотоциклов на Асмоловском циклодроме продолжались десять лет. Общество велосипедистов затратило довольно много сил и средств для устройства здесь трека, удовлетворявшего требованиям гонок, а в расходах участвовало и местное отделение туринг-клуба. Однако популярность велосипедных гонок оказалась непродолжительной, интерес публики к ним стал падать; устройство прочих спортивных соревнований и околоспортивных развлечений удерживало внимание зрителей еще какое-то время. Судя по газетной хронике, летний сезон 1904 г. был последним для циклодрома, расходы по которому не окупались доходом, получаемым от платы за вход и за развлечения. В 1905 г. циклодром был ликвидирован (Хроника. Циклодром, 1905).

Ликвидация циклодрома практически не отразилась на деятельности местных любителей велосипедного туризма, а вот общество велосипедистов-любителей после 1905 года не упоминается ни в справочных книгах по городу, ни в газетной хронике. Какая-то часть его членов могла пополнить состав ростовского туринг-клуба, другая - войти в ростовское общество «Унион». Оно образовалось в Ростове осенью 1904 г. (В обществе «Унион», 1914), когда на циклодроме заканчивался последний, убыточный для общества велосипедистов-любителей, сезон. Со времени образования «Унион» существовал стабильно, в 1914 отметил свое десятилетие. В справочных книгах по городу и в прессе именовали его по-разному: и спортивный кружок, и спортивное общество, и отделение общества велосипедистов «Унион» (Чеботарев, 1911-1912: 197). Ростовское отделение Российского общества туристов объединяло тех, кто предпочитал путешествовать на велосипедах. Практически с момента основания его и вплоть до Первой мировой войны вице-командором, а затем командором его был Н.Н. Роговский, что, видимо, во многом обеспечивало стабильность работы организации. Командоры занимались планированием поездок, но, кроме того, и это - главное, руководили ими. В единственной сохранившейся «Справочной книге» представительства Общества туристов в Донской области на 1904 год описаны полномочия командора и вице-командора во время поездок. Порядок следования велосипедистов, скорость их движения и время остановки определялась 
командорами, которые подавали команды определенным количеством свистков или звонков (Справочная книжка, 1904: 9).

Самым подробным образом изложена также программа местных и дальних поездок членов клуба. В 1904 г. планировалось проведение сорока поездок, которые проводились в основном в города и села Донской области. В качестве дальней поездки на 1904 год предлагался тур НовороссийскТуапсе (Справочная книжка, 1904: 10). Очевидно, одна в сезон продолжительная поездка проводилась ежегодно. В 1910 г., сообщая об открытии Обществом туристов летнего сезона, газета информировала, что в конце мая предлагается экскурсия по Военно-Грузинской дороге «от Владикавказа до Тифлиса. Предварительная запись у командора Н.Н. Роговского» (В обществе туристов, 1910).

В 1906 г. Ростовский туринг-клуб впервые организовал экскурсионные поездки для учащихся городских народных училищ, показав пример организации познавательного и интересного отдыха для детей. Скорее всего, инициатором этой новации выступил А.М. Ильин, вице-командор общества и одновременно преподаватель пятиклассного городского народного училища. В 1907 г. он был избран председателем правления Ростовского туринг-клуба (Хроника, 1907) и, судя по справочным ежегодникам 1910-х гг., не раз на этот пост переизбирался.

Экскурсии лета 1906 г. были бесплатными для школьников, что немаловажно, поскольку в городских народных училищах обучалось немало детей из малообеспеченных ростовских семей. В июне провели пароходную экскурсию в Азов (Хроника, 1906). В июле аналогичную поездку, но уже на поезде, предприняли в Новочеркасск. Более сотни учащихся в двух вагонах, специально прицепленных к дачному поезду, прибыли в Новочеркасск, где их встречали представители Новочеркасского отделения туринг-клуба (Хроника, 1907). Несмотря на положительную оценку этой инициативы правлением общества (В обществе туристов, 1907), дальнейшего развития она не получила. Причинами могли быть и сложности чисто материального характера, и восстановление жесткого внешкольного контроля за учащимися со стороны школьной администрации в постреволюционное время.

Летом 1907 года «Южный телеграф» сообщил о прошедшем в ростовском городском саду состязании любителей тенниса из Ростова и Таганрога, которое закончилось общим счетом в пользу ростовских теннисистов. Судя по фамилиям, среди участников преобладали представители греческих купеческих семейств обоих городов. По сведениям хроникера, соревнование устроил кружок любителей игры в лаун-теннис, который образовался в Ростове в 1906 году. «Учредители его хотят зарегистрироваться как самостоятельное спортивное общество» (Хроника. Лаун-теннис, 1907).

Устав ростовского клуба «Лаун-теннис» был зарегистрирован и опубликован в том же 1907 г. Для города это второй (после Азовско-Донского яхт-клуба) случай, когда спортивная организация была оформлена в виде клуба с разделением членства на почетное, пожизненное и действительное. Почетное членство предоставлялось решением клуба и было выражением его «уважения и признательности» тому или иному лицу. Пожизненное членство можно было купить, если тот или иной действительный член клуба в первый год его существования сделает единовременный взнос, установленный общим собранием клуба. Размер этого взноса сохранившийся устав не приводит, а прочие документы клуба утрачены. Действительными членами могли быть только «лица мужского пола всех званий, состояний и национальностей» с традиционными для всех клубных уставов исключениями. К последним было добавлено, что в клуб не могут быть приняты «профессионалы в спорте». Женщины могли играть в теннис на клубных кортах и участвовать в соревнованиях в качестве посетителей или гостей и обязательно по рекомендации кого-либо из членов клуба.

Цель организации определена была довольно локально: «распространение в Ростове и Нахичевани н/Д игры «Лаун-Теннис» как полезного для здоровья удовольствия». При этом в уставе зафиксировано было право устраивать и другие спортивные мероприятия - футбол, крикет, кегли, фехтование и т.п., а также музыкальные и танцевальные вечера, балы, маскарады, спектакли и другие увеселения для достижения поставленной цели (Устав, 1907: 3-6).

Клуб объединял относительно небольшое число местных любителей тенниса: летом 1913 их насчитывалось 60 человек (Хроника. Лаун-теннис, 1913). В основном это иностранные предприниматели и менеджеры, проживавшие в городе. Бессменным председателем правления клуба был М.Л. Эвморфопулос (Чеботарев, 1911-1912: 198).

Соревнования на кортах общества в городском саду проводились регулярно. В августе разыгрывался приз первенства Юга России. Так, в 1912 г. в состязании приняли участие представители ростовского, таганрогского и казанского клубов лаун-тенниса и английского клуба г. Баку. «От Ростова принимали участие гг. Ботта, Эдвардс, Скараманга и Шашин. Первый приз серебряный кубок и большой золотой жетон выиграл г. Шашин, победив Эдвардса в финальной игре 6-4, 6-1 и 6-2» (Спорт, 1912). Судя по их составу, состязался на ростовских кортах относительно узкий круг лиц.

Летом 1908 года в городе было организовано общество любителей-конькобежцев под председательством Я.К. Шкатина. Уже в зимний сезон 1908-1909 гг. стали проводиться гонки на катке Коммерческого клуба. Так, 27 января 1909 г. соревновались 30 человек, в том числе гонщик из 
Москвы Южин. Для тренировок и бега общество использовало катки Коммерческого клуба и яхтклуба. В 1912 г. в городском саду был устроен еще и каток «Спорт» (Ростов-на-Дону, 2009: 252).

В состязаниях конькобежцев принимали участие и члены других спортивных организаций города. 5 января 1914 член яхт-клуба 3. Рыгельский, состоявший также в Кружке любителей спорта (Кулжинский, Красиловец, 1977: 10), с тремя коллегами совершил пробег Ростов - Таганрог на коньках по льду Дона и Таганрогского залива. За 2 часа 55 мин. было пройдено очень большое, по тем временам, для конькобежцев расстояние - более 70 верст. Инициатором пробега был Рыгельский (Ростов-на-Дону, 2009: 282).

Ростовский кружок любителей спорта возник в 1909 г. и способствовал развитию гимнастики, легкой атлетики, футбола. Занятия с гимнастами и легкоатлетами проводил приглашенный в качестве тренера С. Теодоратис, чемпион Олимпийских игр 1906 года. В 1910 г. членами кружка была организована футбольная команда, в 1912 г. - секция гимнастики и легкой атлетики для женщин. К этому времени кружок объединял 200 чел. (Ростов-на-Дону, 2009: 256). Среди ростовских учеников С. Теодоратиса выделялся Г. Бреев, бронзовый призер I Российской олимпиады (1913 г.) в беге на 100 м и серебряный призер в прыжках в длину с места (Кулжинский, Красиловец, 1977: 8). Он участвовал также в упомянутом выше пробеге конькобежцев.

Справочные книги по городу сообщали, что зимой кружок квартировал в клубе приказчиков, а летом - в здании сельскохозяйственной выставки (Весь Ростов, 1914: 425). На поле, где она устраивалась и которое большую часть весенне-летнего сезона пустовало, спортсмены-любители проводили и футбольные матчи, и спортивные гимнастические праздники. Это не исключало организацию матчей и на площадке Южнорусского общества любителей правильной охоты, расположенной на незастроенном поле между Ростовом и Нахичеванью.

Информация о состязаниях представлена газетными материалами начала 1910-х годов. Преобладают объявления о «Матчах в футбол», о месте их проведения и ценах на билеты для зрителей; реже - краткие сообщения об итогах состоявшейся игры, совсем редко - фото команды кружка. И уж совсем единичные случаи - сообщения о других спортивных акциях ростовских футболистов-любителей. Так, в июле 1912 г. в спортивной хронике отмечалось, что футболисты команды «Маккаби» организовали туристическую группу, «которая отправится пешком 5 августа из Ростова в Таганрог. В экскурсии примут участие все участники предыдущей прогулки 12 мая» (Спорт, 1912). Эта заметка позволяет говорить о том, что в городе накануне Первой мировой войны существовало две команды футболистов; возможно, «Маккаби» - команда Русского общества пароходства и торговли, имевшего контору в Ростове-на-Дону. Номером первым считалась команда под названием «Эспуар», созданная кружком любителей спорта, которая чаще проводила игры как дома, так и на выезде.

По версии очерков «Спорт на Дону», с 1912 г. команда кружка была зарегистрирована во Всероссийской футбольной лиге и принимала участие в первенстве России (Кулжинский, Красиловец, 1977: 10). Объявлениями об играх это не подтверждается. Игры проводились от случая к случаю, когда удавалось договориться о проведении матча в Ростове или на выезде. Из объявлений о матчах известно о существовании футбольных команд в Нахичевани (Футбол, 1914), Таганроге (Перед матчем, 1913), Екатеринодаре (Футбол-матч, 1914), на Сулинском металлургическом заводе (Объявление о матче, 1910).

Посещение футбольных матчей было удовольствием не из дешевых. На матч на площадке Общества любителей правильной охоты ложа стоила 2,5 рубля, что сопоставимо с ложей в городском театре или в кафешантанах, на трибунах - 50 коп., входные билеты - 35 коп. На выставочном поле билеты на футбол в первый ряд стоили 1 рубль, во второй - 75 коп, входные - 50 коп.; бесплатно проходили лишь члены самого кружка любителей спорта. Входные билеты для учащихся были вдвое дешевле, чем для взрослых. (ГАРО.Ф. 2613. Оп. 1. Д. 71. Л. 36).

В 1910-х годах своеобразным увлечением ростовской и нахичеванской молодежи стали гимнастика и катание на роликовых коньках. Первая культивировалась преподавателями гимнастики средних учебных заведений города, среди которых были представители Сокольского спортивного движения из Чехии (Кулжинский, Красиловец, 1977: 10). Способствовала распространению спортивных увлечений и деятельность спортивных обществ любителей, периодически проводивших спортивные праздники. Устраивались и гимнастические выступления учащихся, более или менее публичного характера. Практически ежегодно проводились они учащимися коммерческого училища Ростова. 40-летие Петровского реального училища в 1913 г. также было отмечено гимнастическим представлением, подготовленным реалистами (К 40-летию, 1913).

В 1910 г. в центре города, неподалеку от здания городской думы, был открыт скетинг-ринг специально оборудованное помещение для катания на роликовых, или, как их тогда называли, «колесных» коньках. Отрыт он был в любую погоду и в любой сезон с 11 утра до 12 ночи. Катание проводилось тремя трехчасовыми сеансами, во время которых играл оркестр. Утренний и дневной сеанс стоили 35 коп, вечерний - 50 коп. Для учащихся и военных вход на любой сеанс составлял 25 коп; за прокат коньков нужно было дополнительно заплатить полтинник (Рекламное объявление, 1910). В итоге 
удовольствие покататься на роликах обходилось недешево и было рассчитано на горожан как минимум среднего достатка. Однако ростовцев, желавших покататься, похоже, оказалось немало.

В мае 1911 года открыли скетинг-ринг и в Нахичевани. Заявленная стоимость входных билетов и проката коньков была ниже, чем в Ростове в 1910 г., особенно цена на прокат коньков (25 коп) (Скетинг-ринг, 1911). Видимо, таким в итоге оказался и уровень цен на ростовском катке. Предприниматели обоих торговых городов в начале XX в. хорошо понимали, что устойчивую прибыль приносит массовость продаж, обеспеченная ценами, приемлемыми для большинства покупателей. И обычно стремились к уравниванию цен Ростова и Нахичевани.

Летом 1912 г. «Приазовский край» сообщал: «27 июля на Нахичеванском скетинг-ринге состоялось фигурное состязание при участии местных роликофигуристов. ...В исполнении своих фигур Н. Емельянов остался неподражаем. Большим успехом пользовался Я. Розеншток, считающийся вторым роликофигуристом Ростова и Нахичевани». Присуждение приза Емельянову было неоспоримо, но получение второго приза Д. Афанасьевым вызвало недовольство собравшейся на соревнование публики, посчитавшей, что Я. Розенштока судьи не оценили должным образом (Спорт. Лаун-теннис, 1912).

\section{5. Заключение}

Урабанизационные процессы рубежа XIX-XX веков, экономические изменения повлияли на распространение новых форм времяпрепровождения горожан. С конца XIX века в Ростове-на-Дону сложился устойчивый интерес к спортивным занятиям и оздоровлению организма. Но спорт воспринимался горожанами исключительно как сфера досуга. Спортивная форма досуга объединяла жителей Ростова-на-Дону по интересам, в спортивных клубах. Модное спортивное развлечение горожан, предмет колкостей, острот и сарказмов для фельетонистов ростовских газет, начало обретать накануне Первой мировой войны черты спортивной состязательности. Однако эта тенденция была оборвана войной и революцией 1917 года.

\section{Литература}

Азово-Донской, 1912 - Азово-Донской Яхт-клуб. Ростов-на-Дону. Устав Азовско-Донского ЯхтКлуба: утвержден 5 января 1893 года. Ростов-на-Дону: Типолит. М.И. Осадченко, 1912. 20 с.

В обществе «Унион», 1914 - В обществе «Унион» // Приазовский край. 1914. 24 июня.

В обществе туристов, 1907 - В обществе туристов // Южный телеграф. 1907. 29 марта.

В обществе туристов, 1910 - В обществе туристов // Приазовский край. 1910. 1 мая.

В Яхт-клубе, 1913 - В Яхт- клубе // Приазовский край. 1913. 26 мая.

Весь Ростов н/Д, 1896 - Весь Ростов н/Д на 1896 год. Адрес-календарь, торгово-промышленная справочная книга / Изд. А.И. Тер-Абрамиан. Ростов н/Д.: Типолит. И.А. Абрамиан, 1896. 132 с.

Весь Ростов, 1914 - Весь Ростов. Нахичевань н/Д. 1914 г. Ростов н/Д. Т-л Р. Радомышельского. Харьков. 1914. 640 c.

Войтик, 2013 - Войтик E.A. Роль российской печати в раскрытии спорта как явления досуговой жизни общества во второй половине XIX в. // Журналистский ежегодник. 2013. № 2-1. С. 23-26.

Волошинова, 2013 - Волошинова Л.Ф. Два века городского сада. Серия «Судьбы улиц, площадей, парков». Ростов н/Д.: Донской издательский дом. 2013. 144 с.

ГАРО - Государственный архив Ростовской области.

Гончарова, 2007 - Гончарова O.B. Организация досуга в провинциальном городе на рубеже XIX-XX веков (по материалам Нижнего Поволжья) // Вестник Астраханского государственного технического университета. 2007. № 1 (36). С. 228-232.

Греков, 1912 - Греков A.M. Приазовье и Дон: очерки общественной и экономической жизни края. СПб.: Тип. т-ва «Обществ. польза». 1912. 208 с.

Исторический очерк, 1910 - Исторический очерк // Ростовские-на-Дону бега и скачки. 1910. 18 апреля.

К 40-летию, 1913 - К 40-летию Петровского реального училища, 1913 // Приазовский край. 1913. 9 июня.

Краснянский, 1912 - Краснянский М.Б. Духовная жизнь старого Ростова-на-Дону: историч. изыскания по данным Ростовск. н/Д. гор. Музея. Ростов н/Д.: Типография юж. телеграфа, 1912. 16 с.

Кулжинский, Красиловец, 1977 - Кулжинский И.П., Красиловец Э.Н. Спорт на Дону: Очерки. Ростов н/Д.: Кн. изд-во, 1977. 127 с.

Литягина, 2007 - Литягина А.В. Досуг в городах России во второй половине XIX - начале ХХ в. // Вопросы истории. 2007. № 10. С. 136-142.

Ловелл, 2005 - Ловелл С. Досуг в России: «свободное» время и его использование // Антропологический форум. 2005. № 2. С. 136-173.

Малышева, 2011 - Малышева С.Ю. Праздничный день, досужий вечер: культура досуга российского провинциального города второй половины XIX - начала XX века. M.: ACADEMIA, 2011. $192 \mathrm{c}$. 
Некрылова, 2004 - Некрылова А.Ф. Русские народные городские праздники, увеселения и зрелища. Конец XVIII - начало XX века. СПб.: Азбука-классика, 2004. 256 с.

Объявление о матче. 1910 - Объявление о матче // Приазовский край. 1910. 23 сентября.

Объявление о скачках, 1907 - Объявление о скачках // Южный телеграф. 1907. 27 сентября.

Отчет Азовско-Донского, б.г - Отчет Азово-Донского Яхт-клуба за 1906 г. Б. м. Б. г.

Перед матчем, 1913 - Перед матчем // Приазовский край. 1913. 1 сентября.

Позняк, 2015 - Позняк Т.З. Развеять скуку провинциальной жизни: общественный досуг в городах Дальневосточной окраины в 1850-1870 гг. // Россия и ATP. 2015. № 1 (87). С. 81-93.

Рекламное объявление, 1910 - Рекламное объявление // Ростовские-на-Дону бега и скачки. 1910. 18 апреля.

Ростов-на-Дону, 2009 - Ростов-на-Дону: страницы истории (1749-2009) / [Ред.-сост.:

И.Н. Васильева и др.]. Ростов н/Д.: Омега Паблишер: Золотое сечение, 2009. 831 с.

Самарина, 2019 - Самарина Н.В. Ростовъ - самый удивительный уездный город России. Ростов

н/Д.: Донской издательский дом. 2019. 162 с.

Сидоров, 1996 - Сидоров В.С. Энциклопедия старого Ростова и Нахичевани-на-Дону. Т. 4:

Великий Курган - Гурвич. Ростов н/Д., 1996. 403 с.

Скетинг-ринг, 1911 - Скетинг-ринг // Приазовский край. 1911. 22 мая.

Состав призовых, 1911 - Состав призовых конюшен к предстоящему сезону // Ростовские-на-

Дону бега и скачки. 1911. 22 апреля. 24 апреля.

Спорт, 1912 - Спорт // Приазовский край. 1912. 30 июля.

Спорт. Лаун-теннис, 1912 - Спорт. Лаун-теннис // Приазовский край. 1912. 8 августа.

Справочная книжка, 1904 - Справочная книжка главного представительства на Донскую

область: Сезон 1904 г. / Рос. о-во туристов. Рус. туринг-клуб. Ростов н/Д.: Б. и., 1904. 16 с.

Ульянова, 2011 - Ульянова Г.Н. Досуг и развлечения. Зарождение массовой культуры / Очерки

русской культуры. Конец XIX - начало XX века. Т. 1. Общественно-культурная среда. М: Изд-во

Московского университета, 2011. 880 с. 455-459.

Устав, 1907 - Устав ростовского н/Д клуба «Лаун-теннис» в Ростове н-Д: [Утв. 3 нояб. 1907 г.].

Ростов н/Д.: Б. и., 1907. 19 с.

Футбол, 1914 - Футбол // Приазовский край. 1914. 3 июля.

Футбол-матч, 1914 - Футбол-матч // Приазовский край. 1914. 17 мая.

Хмельницкая, 2011 - Хмельницкая И.Б. Спортивные общества и досуг в столичном городе

начала XX века: Петербург и Москва. М.: Новый хронограф, 2011. 335 с.

Хроника, 1897 - Хроника // Приазовский край. 1897. 15 февраля.

Хроника, 1905 - Хроника // Приазовский край. 1905. 5 октября.

Хроника, 1906 - Хроника // Южный телеграф. 1906. 19 июля.

Хроника, 1907 - Хроника // Южный телеграф. 1907. 1 апреля.

Хроника, 1911 - Хроника // Ростовские-на-Дону бега и скачки. 1911. 6 ноября.

Хроника, 1912 - Хроника // Ростовские на Дону бега и скачки. 1912. 22 апреля.

Хроника. Лаун-теннис, 1907 - Хроника. Лаун-теннис // Южный телеграф. 1907. 26 июня.

Хроника. Циклодром,1905 - Хроника. Циклодром // Приазовский край. 1905. 28 сентября.

Чалхушьян, 2002 - Чалхушьян Г.Х. История города Ростова-на-Дону. Гл. 31. Ч. 1. 1909 //

Донской Временник. 2002. С. 164-212.

Чеботарев. 1912 - Чеботарев Г.А. Ростов-Нахичевань на Дону: Справ. кн.: С пл. г. Ростова, рис., портр. и видами / Г.А. Чеботарев. Ростов-на-Дону: Скл. изд. у авт., 1911-1912. 391 с.

Яхно, 2019 - Яхно О.Н. Досуг в провинциальном городе начала XX века: новые формы организации // История: факты и символы. 2019. № 1 (18). С. 73-84.

Bratolyubova et al., 2019 - Bratolyubova, M.V., Bryzgalova, I.G., Ponomareva, M.A. (2019). Leisure of Rostov-on-Don Citizens in the late XIX - early XX century. Bylye Gody. 54(4): 1726-1736.

\section{References}

Azovo-Donskoi, 1912 - Azovo-Donskoi Yakht-klub. Rostov - na - Donu. Ustav Azovsko-Donskogo Yakht-Kluba: utverzhden 5 yanvarya 1893 goda. [Azov-Don Yacht Club. Rostov - on - Don. Charter of the Azov-Don Yacht Club: approved on January 5, 1893]. Rostov-na-Donu: tipo-lit M.I. Osadchenko, 1912. [in Russian]

Bratolyubova et al., 2019 - Bratolyubova, M.V., Bryzgalova, I.G., Ponomareva, M.A. (2019). Leisure of Rostov-on-Don Citizens in the late XIX - early XX century. Bylye Gody. 54(4): 1726-1736.

Chalkhush'yan, 2002 - Chalkhush'yan, G.Kh. (2002). Istoriya goroda Rostova-na-Donu. Gl. 31. Ch. 1.

1909. [History of Rostov-on-Don. Ch. 31. Part 1. 1909]. Donskoi Vremennik. Pp. 164-212. [in Russian]

Chebotarev, 1912 - Chebotarev, G.A. (1912). Rostov-Nakhichevan' na Donu: Sprav. kn.: S pl. g. Rostova, ris., portr. i vidami [Rostov-Nakhichevan on the Don: Right. Book: From pl. Rostov, Fig., Portraits and Views]. Rostov-na-Donu: skl. izd. u avt., 1911-1912. 391 p. [in Russian]

Futbol, 1914 - Futbol (1914). [Soccer]. Priazovskii krai. 1914. 3 iyulya. [in Russian] 
Futbol-match, 1914 - Futbol-match. (1914). [Football match]. Priazovskii krai. 1914. 17 maya. [in Russian]

GARO - Gosudarstvennyi arkhiv Rostovskoi oblasti [State archive of Rostov region].

Goncharova, 2007 - Goncharova, O.V. (2007). Organizatsiya dosuga v provintsial'nom gorode na rubezhe XIX-XX vekov (po materialam Nizhnego Povolzh'ya) [Organization of leisure in the provincial city at the turn of the 19th-XX centuries (according to the materials of the Lower Volga region)]. Vestnik Astrakhanskogo gosudarstvennogo tekhnicheskogo universiteta. 1(36): 228-232. [in Russian]

Grekov, 1912 - Grekov, A.M. (1912). Priazov'e i Don: ocherki obshchestvennoi i ekonomicheskoi zhizni kraya. [Priazovye and Don: essays of social and economic life of the region]. SPb., tip. t-va «Obshchestv. pol'za». [in Russian]

Istoricheskii ocherk, 1910 - Istoricheskii ocherk (1910). [Historical essay]. Rostovskie-na-Donu bega i skachki. 1910. 18 aprelya. [in Russian]

K 4O-letiyu, 1913 - K 40-letiyu Petrovskogo real'nogo uchilishcha (1913). [To the 40th anniversary of the Petrovsky Real School]. Priazovskii krai. 1913. 9 iyunya. [in Russian]

Khmel'nitskaya, 2011 - Khmel'nitskaya, I.B. (2011). Sportivnye obshchestva i dosug v stolichnom gorode nachala KhKh veka: Peterburg i Moskva. [Sports societies and leisure in the capital city of the beginning of the twentieth century: Petersburg and Moscow]. Moskva: Novyi khronograf. [in Russian]

Khronika, 1897 - Khronika (1897). [Chronicle]. Priazovskii krai. 1897. 15 fevralya. [in Russian]

Khronika, 1905 - Khronika (1905). [Chronicle]. Priazovskii krai. 1905. 5 oktyabrya. [in Russian]

Khronika, 1906 - Khronika (1906). [Chronicle]. Yuzhnyi telegraf. 1906. 19 iyulya. [in Russian]

Khronika, 1907 - Khronika (1907). [Chronicle]. Yuzhnyi telegraf. 1907. 1 aprelya. [in Russian]

Khronika, 1911 - Khronika (1911). [Chronicle]. Rostovskie-na-Donu bega i skachki. 1911. 6 noyabrya.

[in Russian]

Khronika, 1912 - Khronika (1912). [Chronicle]. Rostouskie na Donu bega i skachki. 1912. 22 aprelya.

[in Russian]

Khronika. Laun-tennis, 1907 - Khronika. Laun-tennis [Chronicle. Lawn Tennis]. Yuzhnyi telegraf. 1907. 26 iyunya. [in Russian]

Khronika. Tsiklodrom, 1905 - Khronika. Tsiklodrom (1905). [Chronicle. Tsiklodr]. Priazovskii krai. 1905. 28 sentyabrya. [in Russian]

Krasnyanskii, 1912 - Krasnyanskii, M.B. (1912). Dukhovnaya zhizn' starogo Rostova-na-Donu: istorich. izyskaniya po dannym Rostovsk. [Spiritual life of old Rostov-on-Don: historian. Research according to the data of Rostov]. n/D. gor. Muzeya. Rostov n/D: tipografiya Yuzh. Telegrafa. [in Russian]

Kulzhinskii, Krasilovets, 1977 - Kulzhinskii, I.P., Krasilovets, E.N. (1977). Sport na Donu: Ocherki [Sports on the Don: Essays]. Rostov n/D: Kn. izd-vo. [in Russian]

Lityagina, 2007 - Lityagina, A.V. (2007). Dosug v gorodakh Rossii vo vtoroi polovine XIX - nachale $\mathrm{XX}$ v. [Leisure in the cities of Russia in the second half of the XIX - the beginning of the XX century]. Voprosy istorii. 10: 136-142. [in Russian]

Malysheva, 2011 - Malysheva, S.Yu. (2011). Prazdnichnyi den', dosuzhii vecher: kul'tura dosuga Rossiiskogo provintsial'nogo goroda vtoroi poloviny XIX - nachala XX veka. [Holiday, evening: culture of leisure of the Russian provincial city of the second half of the 19th - the beginning of the 2oth century]. M.: ACADEMIA. [in Russian]

Nekrylova, 2004 - Nekrylova, A.F. (2004). Russkie narodnye gorodskie prazdniki, uveseleniya i zrelishcha. Konets XVIII - nachalo XX veka. [Russian folk city holidays, entertainment and spectacles. End of the XVIII - beginning of the XX century]. SPb: Azbuka-klassika. [in Russian]

Ob"yavlenie o matche, 1910 - Ob"yavlenie o matche. (1910). [Match announcement]. Priazovskii krai. 1910. 23 sentyabrya. [in Russian]

Ob"yavlenie o skachkakh, 1907 - Ob"yavlenie o skachkakh. (1907). [Horse Racing Announcement]. Yuzhnyi telegraf. 1907. 27 sentyabrya. [in Russian]

Otchet Azovsko-Donskogo, b.g - Otchet Azovo-Donskogo Yakht-kluba za 1906 g. (b.g). [Report of the Azov-Don Yacht Club for 1906]. B. m. B. g. [in Russian]

Pered matchem, 1913 - Pered matchem. (1913). [Before the match]. Priazovskii krai. 1913. 1 sentyabrya. [in Russian]

Poznyak, 2015 - Poznyak, T.Z. (2015). Razveyat' skuku provintsial'noi zhizni: obshchestvennyi dosug v gorodakh Dal'nevostochnoi okrainy v 1850-1870 gg. [Dispel the boredom of provincial life: public leisure in the cities of the Far Eastern outskirts in 1850-1870]. Rossiya i ATR. 1(87): 81-93. [in Russian]

Reklamnoe ob"yavlenie, 1910 - Reklamnoe ob"yavlenie (1910). [Advertisement]. Rostovskie-na-Donu bega i skachki. 1910. 18 aprelya. [in Russian]

Rostov-na-Donu, 2009 - Rostov-na-Donu: stranitsy istorii (1749-2009). [Rostov-on-Don: history pages (1749-2009)]. Rostov-na-Donu: Omega Pablisher: Zolotoe sechenie, red.-sost.: I.N. Vasil'eva i dr. 2009. [in Russian]

Samarina, 2019 - Samarina, N.V. (2019). Rostov - samyi udivitel'nyi uezdnyi gorod Rossii [Rostov the most amazing county city of Russia]. Rostov-na-Donu. Donskoi izdatel'skii dom. [in Russian] 
Sidorov, 1996 - Sidorov, V.S. (1994). Entsiklopediya starogo Rostova i Nakhichevani-na-Donu. [Encyclopedia of old Rostov and Nakhichevan-on-Don]. T. 4: Velikii Kurgan - Gurvich. Rostov n/D. [in Russian]

Sketing-ring, 1911 - Sketing-ring (1911). [Roller-skating rink]. Priazovskii krai. 1911. 22 maya. [in Russian]

Sostav prizovykh, 1911 - Sostav prizovykh konyushen k predstoyashchemu sezonu. (1911). [Composition of prize stables for the upcoming season]. Rostovskie-na-Donu bega i skachki. 1911. 22 aprelya. 24 aprelya. [in Russian]

Sport, 1912 - Sport [Sports]. Priazovskii krai. 1912. 30 iyulya. [in Russian]

Sport. Laun-tennis, 1912 - Sport. Laun-tennis [Sports. Lawn Tennis]. Priazouskii krai. 1912. 8 avgusta. [in Russian]

Spravochnaya knizhka, 1904 - Spravochnaya knizhka glavnogo predstavitel'stva na Donskuyu oblast': Sezon 1904 g. Ros. o-vo turistov. Rus. turing-klub..(1904). [Reference book of the main representative office in the Don region: 1904 season/Growing. about tourists. Rus. touring club]. Rostov n/D: B. i., 1904. 16 p. [in Russian]

Ul'yanova, 2011 - Ul'yanova, G.N. (2011). Dosug i razvlecheniya. Zarozhdenie massovoi kul'tury. [Leisure and entertainment. The birth of mass culture]. Ocherki russkoi kul'tury. Konets XIX nachalo XX veka. T. 1. Obshchestvenno-kul'turnaya sreda. M: Izd-vo Moskovskogo universiteta, pp. 455-459. [in Russian]

Ustav, 1907 - Ustav rostovskogo n/D kluba «Laun-tennis» v Rostove n-D. Utv. 3 noyab. 1907 g. [Charter of the Rostov N/A club "Lawn Tennis" in Rostov N-D: Utv. Nov 3. 1907]. Rostov n/D: B. i., 1907. [in Russian]

V obshchestve «Union», 1914 - V Obshchestve «Union». (1914). [In the Union Society]. Priazovskii krai. 1914. 24 iyunya. [in Russian]

V obshchestve turistov, $1907-\mathrm{V}$ obshchestve turistov (1907). [In the society of tourists]. Yuzhnyi telegraf. 1907. 29 marta. [in Russian]

V obshchestve turistov, $1910-\mathrm{V}$ obshchestve turistov (1910). [In the society of tourists]. Priazovskii krai. 1910. 1 maya. [in Russian]

V Yakht-klube, 1913 - V Yakht- klube (1913). [At the Yacht Club]. Priazovskii krai. 1913. 26 maya. [in Russian]

Ves' Rostov n/D, 1896 - Ves' Rostov n/D na 1896 god. Adres-kalendar', torgovo-promyshlennaya spravochnaya kniga. (1896). [All Rostov n/A for 1896. Calendar Address, Commercial and Industrial Reference Book/ed. A.I. Ter-Abramian]. Rostov n/D: tipo-lit. I.A. Abramian, 1896. [in Russian]

Ves' Rostov, 1914 - Ves' Rostov. Nakhichevan' n/D. 1914 g. (1914). [All of Rostov. Nakhichevan n/D. 1914.]. Rostov n/D. T-l R. Radomyshel'skogo. Khar'kov. 1914. [in Russian]

Voitik, 2013 - Voitik, E.A. (2013). Rol' rossiiskoi pechati v raskrytii sporta kak yavleniya dosugovoi zhizni obshchestva vo vtoroi polovine XIX v. [The role of the Russian press in the disclosure of sports as a phenomenon of leisure life in society in the second half of the XIX century]. Zhurnalistskii ezhegodnik. 2-1: 23-26. [in Russian]

Voloshinova, 2013 - Voloshinova, L.F. (2013). Dva veka gorodskogo sada. Seriya «sud'by ulits, ploshchadei, parkov». [Two centuries of the city garden. Series "fate of streets, squares, parks"]. Rostov-n/D: Donskoi izdatel'skii dom. [in Russian]

Yakhno, 2019 - Yakhno, O.N. (2019). Dosug v provintsial'nom gorode nachala XX veka: novye formy organizatsii. [Leisure in the provincial city of the beginning of the 2oth century: new forms of organization]. Istoriya: fakty i simvoly. 1(18): 73-84. [in Russian]

\section{Спортивные общества и досуг в Ростове-на-Дону на рубеже XIX-XX веков}

Мария Викторовна Братолюбова а, *

a Южный федеральный университет, Российская Федерация

Аннотация. Статья посвящена важной составляющей городского образа жизни Ростова-наДону - досугу в конце XIX - начале XX вв. Рассмотрен спортивный аспект истории досуга в уездном Ростове-на-Дону. Показано, как в среде средних слоев горожан к концу XIX в. отчетливо обозначились как тенденции к объединению для совместного проведения свободного времени, так и к разумным, развивающим формам досуговых занятий. К последним автор относит организации для совместных занятий спортом. В Ростове-на-Дону шло быстрыми темпами развитие форм досуга, связанных с приобщением к физкультуре и спорту. Популярными становились занятия физкультурой

\footnotetext{
${ }^{*}$ Корреспондирующий автор

Адреса электронной почты: mvbratolyubova@sfedu.ru (M.В. Братолюбова)
} 
и спортом, принимавшие общественные формы: общества конькобежцев и лыжебежцев, велосипедистов и футболистов.

Автор делает вывод о том, что с последней четверти XIX в. спорт стал модным и всеобщим увлечением в Ростове-на-Дону, создавались первые спортивные клубы и организовывалась первые соревнования. Некоторые виды спортивных занятий, эволюционируя в профессиональный спорт, уже на рубеже XIX-XX вв. превращались в массовые зрелища, генерировавшие азарт болельщиков (бега и скачки, борьба). В статье показано, как спортивные занятия были еще и возможностью для общения единомышленников. Досуг создавал возможности для самореализации горожан и способствовал развитию институтов гражданского общества.

Модное спортивное развлечение горожан накануне Первой мировой войны начало обретать черты спортивной состязательности. Однако эта тенденция была оборвана Первой мировой войной и революционными потрясениями в России в начале XX века.

Ключевые слова: Ростов-на-Дону, провинциальный город, спортивная досуговая деятельность, спортивные общественные организации и клубы. 